\title{
Seroprevalence of Brucella abortus in the Bamenda Municipal Abattoir of the Western Highlands, of Cameroon
}

\author{
Anold Tatah Kong ${ }^{1,3 *}$, Munji Victorine Nsongka ${ }^{2}$, \\ Salome Mokabe Itoe ${ }^{3}$, Arnaud Touko Hako ${ }^{3}$, \\ Isabelle Leinyuy ${ }^{2}$
}

${ }^{1}$ Department of Development Studies, Pan African Institute for Development - West Africa (PAIDWA) Buea P.O. Box 133, Buea, Cameroon.

${ }^{2}$ Institute of Agricultural Research for Development (IRAD) Bambui, North West Region, Cameroon.

${ }^{3}$ School of Agriculture and Natural Resources, Catholic University Institute of Buea (CUIB) P.O. Box 563, Buea.

ARTICLE INFO

Article No.: 082216135

DOI: 10.15580/GJAS.2016.8.082216135

Submitted: 22/08/2016

Accepted: 27/08/2016

Published: 28/09/2016

${ }^{*}$ Corresponding Author

Anold Tatah Kong

E-mail: arnoldkong26@yahoo.

com

Phone: 237670233746

\section{Keywords:}

Brucella abortus, Competitive

ELISA, Seroprevalence, cattle,

Bamenda municipality abattoir,

western highlands

\section{ABSTRACT}

Brucellosis is one of the most notorious and widespread zoonosis caused by Brucella abortus. It is of serious economic implications to the cattle industry and thus enormous financial losses to most countries. This study focused on it serological prevalence at the Nkwen main abattoir of Bamenda (Northwest region, Cameroon) from June to September 2013. Blood samples were collected from 198 cattle and the sera were screened using the competitive enzyme linked immuno sorbent assay (C-ELISA). Results showed a seroprevalence of $4.04 \%$ in the cattle population screened. A percentage of $4.40 \%$ of the 111 bulls and $3.45 \%$ of the 87 cows were recorded as infected. There was no evidence $(P>0.05)$ of differences in sex on the seroprevalence of brucellosis in cattle. There was no association between brucella infection and age $(P>0.05)$. About three percent of cattle were positive for those within $(<5)$ age group with $5(4.67 \%)$ for those above 5 years of age. The two breeds commonly consumed in the area the Red and White Fulanie with the Red Fulani having a higher infection than the White Fulani $(P<0.05)$. The study also showed that Brucella infection was dependent on location as 5 out of the 15 villages accounting for $100 \%$ infection namely: Fundong $(37.5 \%)$, Wum (25\%), Nso (Jakiri) $(12.5 \%)$, Metah (12.5\%) and Fonta (12.5\%). From these results it was concluded that brucellosis is present in the population of cattle screened. There is therefore the need for good control measures and sanitary conditions to limit the spread of the disease. 


\section{INTRODUCTION}

There has been increasing demand for livestock products worldwide. Most governments in an effort to increase the availability of protein rich foods have laid emphasis on the improvement of the health status of cattle. Diseases are often transmitted from cattle to man leading to health impairment.

In Cameroon, the livestock sub-sector plays a significant role in its economy (Aliou, 2004). Generally it is the source of revenue for livestock owners. According to (Aliou, 2004), it serves about $30 \%$ of Cameroon's rural population, representing $9 \%$ of agricultural productions and contributes some 125 billion FCFA to the Gross Domestic Product. The role of livestock, in ameliorating the nutritional status of the Cameroonian population cannot be over emphasized. Furthermore, it generates employment opportunities to millions of Cameroonians, like breeders, middlemen in cattle trade, transformers, transporters and butchers. Livestock products, especially beef constitutes a significant part of the main diet of more than $60 \%$ of the population. Other products like milk, hides and skin are also highly consumed in some parts of the country, especially in the North West (N.W.) and Northern Regions (Aliou, 2004). Livestock products, especially dairy, make unique contribution to human nutrition by providing micronutrients in bio-available form such as vitamin $A$, in addition to carbohydrates, protein and calcium and so if contaminated, will lead to a significant health defect on the population.

Brucellosis, caused by a small non-motile aerobic and facultative intracellular gram-negative coccobacilli of the genus Brucella (Brucella abortus), is a common cattle disease (CFSPH, 2009 ). Today, the disease is only spatially spread in the world as it has been eradicated in some developed countries (Geering et al., 1995; CFSPH, 2009). Brucellosis is one of the most notorious and widespread zoonosis (Lopes et al., 2010), and it is often transmitted from one animal to another through contact with infected animals, infected semen, and after birth (Lapaque et al., 2010). Though it has been eradicated in many developed countries in Europe, Australia, New Zealand, Canada and Japan (Geering et al., 1995) it remains an uncontrolled problem in regions of high endemicity such as Africa, Mediterranean, Middle East, Asia and Latin America (Refai, 2002).

From a public health point of view, brucellosis is an occupational disease affecting slaughter-house workers, butchers, and veterinarians (Plummet et al., 1998). Non occupational exposure is mainly through the consumption of unprocessed infected animal products (Hassan et al., 2012). Clinical signs of animal brucellosis such as abortion, weak offspring, weight loss, lameness, reduction in milk yield and pathological lesions such as necrotizing placentitis, disseminated inflammatory granuloma in aborted foetal tissue brachio or intestinal pneumonia vary from one animal species to the other with severe negative impact on animal health and productivity (Radostits et al., 2000; Antiabong et al., 2009). In humans, the symptoms of this disease are extreme weakness, pain in muscles, joint, and/or back, headache, undulant fever, malaise, anorexia, fatique and night sweats. Mortality is reported to be negligible, but the illness can last for several years (WHO, 2003). Other symptoms which may never go away or reoccur are; arthritis (Inflammation of joints), orchitis (swelling/inflammation of the testicle and scrotum) painful inflammation of the epididymis (Plummet et al., 1998), endocarditis (swelling of the heart), neurologic symptoms (in up to $5 \%$ of all cases). Chronic fatigue, depression, swelling of the liver and/or spleen (CDC, 2012) are among the health deteriorating effects caused by brucellosis.

Brucellosis also has serious economic implications to the cattle industry and thus enormous financial losses to most countries (Shey-Njila, 2004). In some parts of Africa and India, the infection is much more widespread than suspected. More foci remain to be discovered by the application of laboratory methods in epidemiological investigations (Shey-Njila et al., 2005). Apart from the fact that the disease has tremendously increased in regions of high endemicity because of greater emphasis on increased animal production and aggregation under poor hygienic condition, the transportation of animals from one area to the other increases the vulnerability of the population. The vulnerability is more pronounced with dairy production units which have developed around rapidly growing urban centres. The disease is present throughout the African continent (Chimana et al., 2010; Matope et al. 2011; Megersa et al., 2011) and has also been reported in two of Cameroon's neighboring countries, Nigeria and Chad (Bertu et al., 2011; Schelling et al., 2003).

Although it is anticipated that brucellosis is present in the major animal producing areas, the current status of brucellosis in Cameroon which is a bread basket of the central African sub region is unclear. This is a major concern to veterinarians and physicians (Bayemi et al., 2009).

The limitation of data on the seroprevalance of the disease and the non-reliability of that available (Shey-Njila et al., 2005) necessitates a study for the development of control measures aimed at improving productivity in Cameroon (Bertu et al., 2011). This work is therefore aimed at assessing the seroprevalence of brucellosis in the Nkwen abattoir in the North West Region of Cameroon, one of the major cattle producing areas in Cameroon. The specific objectives were; to estimate the serological prevalence of Brucella abortus in cattle and to determine the effect of breed, sex, age and location on the prevalence of Brucella abortus in cattle.

\section{MATERIALS AND METHODS}




\subsection{Description of the study area}

The work was done at the Bamenda municipal abattoir location in the Western Highlands agro-ecological zone. Bamenda is located between latitudes $5^{\circ} 55^{\prime \prime} \mathrm{N}$ and $6^{\circ}$ $30^{\prime \prime} \mathrm{N}$ and longitudes $10^{\circ} 25^{\prime \prime} \mathrm{E}$ and $10^{\circ} 67^{\prime \prime} \mathrm{E}$. The town has an altitude that ranges from $1200-1700 \mathrm{~m}$, and is divided into two parts by an escarpment; a low lying gently undulating part with altitudes ranging from 1200 to $1400 \mathrm{~m}$, with many flat areas that are usually inundated for most parts of the year, and an elevated part at 1400 to $1700 \mathrm{~m}$ altitude that forms the crest from which creeks, and streams, supplying the low lying parts take their rise.

This area has two seasons; a long rainy season, which runs from mid-March to mid- October and a short dry season that spans from mid-October to mid-March. Mean annual temperatures stand at $19.9{ }^{\circ} \mathrm{C}$. January and February are the hottest months with mean monthly temperatures of $29.1{ }^{\circ} \mathrm{C}$ and29.7 ${ }^{\circ} \mathrm{C}$, respectively. Annual rainfall ranges from $1300-3000 \mathrm{~mm}$ (Ndenecho, 2005). The main human activity in and around this area is agriculture, which according to Grassfield Participatory-Decentralised and Rural Development Project (GP-DERUDEP, 2006) involves over $70 \%$ of the population. Approximately $60 \%$ of the North West Region is viable for livestock production. This represents a potential of $1,054,914$ hectares of natural pastures which is distributed among the different divisions. The area is estimated to have 425,062 cattles, with the Donga-Mantung Division having the highest ( 129,754 ) followed by Menchum Division with a total of 62,920 and Ngoketunjia with only 6,649 cattle. Its agro-climatic conditions are favourable for cattle rearing. The extensive, semi-intensive and intensive systems of cattle rearing are practised in the area. The extensive system is highly practiced in Donga Mantung, Menchum, Bui, Boyo, Momo and Mezam Divisions. The Ndop plain in Ngoketunjia Division serves as an important transhumance zone for the cattle population from neighbouring Divisions and the West Region.

Cattle produced in this region is also sold in other cities in Cameroon and some neigbouring countries like the Central African Republic, Gabon, and Equitoral Guinea.

The Nkwen abattoir is the largest in the Region and often receives cattle from the various production zones.

\subsection{Experimentation}

The study was done between June and September 2013. Blood samples were randomly collected from a total of 198 cattle (111 bulls and 87 cows) about to be slaughtered. Samples were collected from two breeds: the White Fulani and Red Fulani, with ages ranging between 2 to 11 years. The animals came from different locations in the Region.

\subsubsection{Blood sample and serum collection}

Before sample collection, each animal was identified according to its location, breed, age and sex. About $5 \mathrm{ml}$ of blood was collected from the jugular vein of each of the animals at the slaughter house using vacutainers, blood collection needles and tubes. The samples were then transported in a cooler (flask) to the Animal Production and Health laboratory of IRAD Bambui, where they were centrifuged at a temperature of $25^{\circ} \mathrm{C}$ and speed of $2500 \mathrm{rpm}$ for 10 minutes. Serum was then collected and stored at $-20^{\circ} \mathrm{C}$ for further analysis.

\subsubsection{Competitive ELISA Test procedure}

Serum samples were used for the competitive ELISA screening.

All the Brucella-AB C-ELISA test kits: were obtained from Svanova Biotech AB, Uppsala Science Park, Sweden. The tests were performed according to the manufacturer's instructions (SVANOVA, Sweden, 2005).

\subsection{Statistical Analysis:}

Data obtained from the study were subjected to Chisquare statistical test to determine the association between Brucella infection and sex, age and breed. Descriptive statistics was used to compare the prevalence of Brucella abortus with location.

\section{RESULTS AND DISCUSSION}

Of the 198 cattle screened over the entire period of the study 8 were found to be positive with the competitive ELISA test giving a seroprevalence of $4.04 \%$. These findings are close to those of Shey-Njila (2004) who reported that in the Dschang abattoir in Cameroon, brucellosis had a prevalence of 4.88 to $9.64 \%$. Similar findings have also been reported at the Institute of Animal Research at Bambui, Cameroon with a prevalence of $4 \%$ in cattle reared at ranches in traditional systems. However, the results are lower than those reported by Shey-Njila et al. (2005) who observed that at the Yaoundé abattoir, bovine brucellosis has a seroprevalence between 7.2 and $8.8 \%$ an indication that location has an effect on the prevalence. Much higher prevalence has been reported in other parts of the world (Bornarel et al., 1987; Domenech et al., 1980). The prevalence of $(4.04 \%)$ recorded in this study may result from the fact that some animals may have been vaccinated since some $\mathrm{PI}$ values were negative. On the other hand the prevalence of the disease in the cattle to be slaughtered could be due to improper hygienic practices in disposing aborted foetuses, placenta and vaginal discharges which contain virulent Brucella abortus thus contaminating the pasture and water, serving as reservoirs of infection to other cattle. Infected cow and bulls are not normally isolated or culled from 
the herd thus making transmission and infection a continuous cycle.

\section{Effect of Sex Distribution on brucella infection in cattle:}

From table 1 , of the 198 samples screened, 111 were males and 87 females. A percentage of $(4.50 \%)$ in males and $(3.45 \%)$ in females were recorded. There was no significant association between brucella infection and $\operatorname{sex}(P>0.05)$.

Similarly findings of $8.4 \%$ seroprevalence had been reported in Cameroon by Bayemi et al. (2009) where Holstein cattle from small scale dairy production systems were screened for Brucella abortus antibodies in 21 villages. Of the 192 cows tested by the later, 14 were infected giving a within-sex seroprevalence of $7.3 \%$ while $6 / 74$ bulls were infected with a seroprevalence of $8 \%$. There was no significant difference between sexes. Matope et al. (2011) carrying out a cross-sectional study of a total of 1,440 cattle from 203 herds in Zimbabwe also reported similar results. Though the seroprevalence was independent of sex, it decreased with increasing age. On the contrary, Chimana et al., (2010) reported more seropositive cases in bulls $(12.5 \%)$ when compared to females $(8.1 \%)$. The relationship between sex distribution and brucella infection has been seen to vary with different cattle populations. The lack of difference in seroprevalence reactors between males and females may indicate that the risk of infection with Brucella species is independent of sex of cattle and could be attributed to the fact that males are also carriers of the disease and the males brought into the abattoir during that period could be carriers.

\section{Effect of Age Distribution on brucella infection in cattle}

Table 2 Indicates that 3(3.3\%) out of 107 cattle aged $<5$ years were positive. For those within the age band $>5$ years, $5(4.67 \%)$ out of 91 were positive. There was no association between brucella infection and age $(P>0.05)$. The inexistence of a difference in seroprevalence of different age groups of animals $>5$ years accounted for more than half of the infected animals. This association of age with seropositivity of Brucella infection is consistent with the findings of earlier studies by Bayemi et al. (2009). Of the 192 cows studied by the later, 14 were infected giving a within-sex seroprevalence of $7.3 \%$ while $6 / 74$ bulls were infected with a seroprevalence of $8 \%$. There was no evidence $(P=0.11)$ of differences in seroprevalence between age groups although animals above one year and below three years accounted for nearly half of the infected animals. Cadmus et al., (2008) also observed no difference between cattle $>3$ years and 1-3 years old, whereas Matope et al.(2011) reported decreased frequency of brucellosis with increasing age. The non-association between age and brucella infection of cattle in this study could be attributed to the fact that the age grouping between the animals were small.

\section{Effect of Breed Distribution on brucella infection in cattle}

In the study, 77 of the cattle were of the Red Fulani breed and 121 were White Fulani breed. 7 (9.09\%) out of 77 were positive for the Red Fulani and $1(0.83 \%)$ out of 121 was positive for the White Fulani breed. Results on breed (Table 3 ) showed that the Red Fulani had a higher infection than the White Fulani. There was an association between brucella infection and breed $(\mathrm{P}<0.05)$. The Red Fulani showed a seroprevalence of $(87.5 \%)$ against $(12.5 \%)$ for white Fulani. Indicating that infection of brucellosis is dependent on breed $(P<0.05)$. Bertu et al. (2011) found out that, in the Benue state in Nigeria, Red Fulani breed recorded 11.1\% serprevalence against $10.4 \%$ for the White Fulani. In another study using the Red Fulani and the Bunaji breed, Cadmus et al. (2008) found that the Red Fulani breed had the most positive reaction. This could be an indication that the Red Fulani breed is the most vulnerable.

\section{Effect of Location on brucella infection in cattle}

From table 4, samples were collected from animals which came from 15 villages and the villages were further divided into 8 subdivisions. The study showed that Brucella infection is dependent on location and five (5) out of the 15 villages accounted for $100 \%$ percent of infected animals namely Fundong (37.5\%), Wum (25\%), Nso (12.5\%), Metah (12.5\%) and Fonta (12.5\%). This could be attributed to the fact that more animals came from these villages. On the contrary Matope et al. (2011) who carried out a cross-sectional study of 1,440 cattle from 203 herds in 6 different areas of Zimbabwe showed that in individual cattle, the area of origin was independently associated with brucellosis seroprevalence.

Results of the serological prevalence of brucellosis according to sex, age, breed and location are presented in Table 1, 2, 3, and 4 respectively. 
Table 1: Effect of Sex distribution on brucella infection in cattle

\begin{tabular}{|c|c|c|c|c|c|c|c|}
\hline \multirow[t]{2}{*}{ Sex } & \multicolumn{2}{|l|}{ Infected } & \multicolumn{2}{|c|}{ Non-infected } & \multicolumn{2}{|l|}{ Total } & \multirow[t]{2}{*}{$\mathrm{X}^{2}$} \\
\hline & Number & Percentage & Number & Percentage & Number & Percentage & \\
\hline Male & 5 & 4.50 & 106 & 95.50 & 111 & 100 & \\
\hline Female & 3 & 3.45 & 84 & 96.65 & 87 & 100 & \\
\hline Total & 8 & 4.04 & 190 & 95.06 & 198 & 100 & ns \\
\hline
\end{tabular}

$\mathrm{ns}=$ no significant difference $(\mathrm{P}>0.05)$

Table 2: Effect of Age distribution of brucella infection in cattle

\begin{tabular}{|c|c|c|c|c|c|c|c|}
\hline \multirow[t]{2}{*}{ Age } & \multicolumn{2}{|l|}{ Infected } & \multicolumn{2}{|c|}{ Non-infected } & \multicolumn{2}{|l|}{ Total } & \multirow[t]{2}{*}{$\mathrm{X}^{2}$} \\
\hline & Number & Percentage & Number & Percentage & Number & Percentage & \\
\hline$>3-5$ & 3 & 3.3 & 87 & 96.7 & 91 & 100 & \\
\hline$>5$ & 5 & 4.67 & 102 & 95.33 & 107 & 100 & \\
\hline Total & 8 & 4.04 & 190 & 95.06 & 198 & 100 & Ns \\
\hline
\end{tabular}

$\mathrm{ns}=$ no significant difference $(\mathrm{P}>0.05)$

Table 3: Effect of Breed distribution on brucella infection in cattle

\begin{tabular}{|c|c|c|c|c|c|c|c|}
\hline \multirow[t]{2}{*}{ Breed } & \multicolumn{2}{|l|}{ Infected } & \multicolumn{2}{|c|}{ Non-infected } & \multicolumn{2}{|l|}{ Total } & \multirow[t]{2}{*}{$\mathrm{X}^{2}$} \\
\hline & Number & Percentage & Number & Percentage & Number & Percentage & \\
\hline $\begin{array}{l}\text { White } \\
\text { Fulani }\end{array}$ & 1 & 0.83 & 120 & 99.07 & 121 & 100 & \\
\hline $\begin{array}{l}\text { Red } \\
\text { Fulani }\end{array}$ & 7 & 9.09 & 70 & 90.01 & 77 & 100 & \\
\hline Total & 8 & 4.04 & 190 & 95.06 & 198 & 100 & $P<0.05$ \\
\hline
\end{tabular}

$\mathrm{P}<0.05$

Table 4: Effect of Location distribution on brucella infection in cattle

\begin{tabular}{|c|c|c|c|c|c|c|c|}
\hline \multirow{2}{*}{ Subdivision } & \multicolumn{2}{|l|}{ Infected } & \multicolumn{2}{|c|}{ Non-infected } & \multicolumn{2}{|l|}{ Total } & \multirow{2}{*}{$\begin{array}{l}\text { Infection } \\
\text { Percentage }\end{array}$} \\
\hline & Number & Percentage & Number & Percentage & Number & Percentage & \\
\hline Tuba & 1 & 4.8 & 20 & 95.2 & 21 & 100 & 12.5 \\
\hline Wum & 2 & 2.6 & 75 & 97.4 & 77 & 100 & 25 \\
\hline Fundong & 3 & 7.3 & 38 & 92.7 & 41 & 100 & 37.5 \\
\hline Jakiri & 1 & 5.3 & 18 & 94.7 & 19 & 100 & 12.5 \\
\hline Misaje & 0 & 0 & 19 & 100 & 19 & 100 & 0 \\
\hline Mbengwi & 1 & 6.3 & 15 & 93.7 & 16 & 100 & 12.5 \\
\hline Bamenda & 0 & 0 & 4 & 100 & 4 & 100 & 0 \\
\hline Awing & 0 & 0 & 1 & 100 & 1 & 100 & 0 \\
\hline Total & 8 & 4.04 & 190 & 95.06 & 198 & 100 & 100 \\
\hline
\end{tabular}




\section{CONCLUSION}

Brucellosis is a real disease of cattle in the Western Highlands of Cameroon with a prevalence of $4.04 \%$. The prevalence of the disease is not affected by sex and age but is highly influenced by location and breed. The prevalence is highest in cattle from the Fundong area. The Red Fulani breed is the most vulnerable. Given that cattle from these areas are often transported to other part of the country, proper inspection of cattle to be slaughtered should be ensured and good sanitary practices be carried out by abattoir workers to minimize the spread of this disease to humans. This should be complimented by proper cooking at the households' level.

\section{ACKNOWLEDGEMENT}

The authors acknowledge logistic support from the Institute of Agricultural Research for Development (IRAD) Bambui, North West Region Cameroon. Sincere gratitude also goes to Doctor Mbomi S. Elizabeth for inspiring and directing the work.

\section{REFERENCES}

Aliou S (2004). Socio-Economic Assessment of Traditional Grazing Amongst Pastoralist Groups: Case Study of the Mbororo Fulani in the North west Province of Cameroon", Unpublished Memoir Submitted in Partial Fulfillment of the Requirement for the Award of the Diploma Igenieur Agronome, Department of Agronomy and Agricultural Sciences, University of Dschang.

Antiabong JF, Yakubu B, Owolodun OA, Bertu W and Ocholi RA (2009). Molecular detection of Brucella spp. from broth culture of clinical samples in Nigeria: Its role in vaccine quality control.

Bayemi PH, Webb EC, Nsongka MV, Unger H, Njakoi H (2009). Prevalence of Brucella abortus antibodies in serum of Holstein cattle in Cameroon. Trop Anim Health Prod, 41:141-144.

Bertu WJ, Amahyel M, Gusi, Moses Hassan, Esther Mwankon, Reuben AO, Daniel D, lor, Bakari AH, Gideon I, Theresia H, Abdoel \& Henk LS (2011). Serological evidence for brucellosis in Bos indicus in Nigeria

Bornarel P, Akakpo AJ \& Tuekam (1987). Epidémiologie de la brucellose bovine en Afrique tropicale. 3. Enquête sérologique au Cameroun. Revue Méd. Vét., 138 (1): 55-58 (in French).

Cadmus SIB, Adesokan HK, Stack J (2008). The use of the milk ring test and Rose Bengal test in brucellosis control and eradication in Nigeria. J S Afr Vet Med Ass 2008, 79:113-115.

Center for Food Security and Public Health (2009) College of Veterinary Medicine lowa State University
Centers for Disease Control and Prevention [CDC] (2012). Brucellosis-signs and symptoms.

Chimana HM, Muma JB, Samui KL, Hangombe BM, Munyeme M, Matope G, Phiri AM, Godfroid J, Skjerve E, Tryland M (2010). A comparative study of the seroprevalence of brucellosis in commercial and small-scale mixed dairy-beef cattle enterprises of Lusaka province and Chibombo district, Zambia. Trop Anim Health Prod 42:1541-1545. PubMed Abstract | Publisher Full Text

Domenech J, Lucet P \& Grillet C (1980a). La brucellose bovine en Afrique centrale: I. -Méthodes d'enquête utilisables en milieu tropical. Rev. Elev. Méd. vét. Pays trop., 33 (3): 277-284 (in French).

Geering WA, Forman JA and Nunn MJ (1995). Exotic Diseases of Animals. Aust. Gov. Publishing Service, Canberra, Australia, pp: 301-306.

GP-DERUDEP. Grassfield Participatory: Decentralized and Rural Development Project. (2006). Baseline study of the North West Province. SIRDEP Bamenda Cameroon. 298pp.

Hassan M Mai, Peter Cl, Junaidu K and Peter NT (2012). A large seroprevalence survey of brucellosis in cattle herds under diverse production systems in northern Nigeria.

Lapaque N, Moriyon I, Moreno E and Gorvel JP (2005). Brucella lipopolysaccharide acts as a virulence factor. Curr. Opin. Microbiol., 8: 60-66.

Lopes LB, Nicolino R and Haddad JPA (2010). Brucellosis-Risk Factors and Prevalence: A Review, 4, 72-84

Matope G, Bhebhe E, Muma JB, Oloya J, Madekurozwa $R L$, Lund A, Skjerve E (2011). Seroprevalence of brucellosis and its associated risk factors in cattle from small holder dairy farms in Zimbabwe. Trop Anim Health Prod, 43:975-982. PubMed Abstract | Publisher Full Tex

Megersa Bekele Demelash Biffa, Fekadu Niguse, Tesfaye Rufael, Kassahun Asmare-and Eystein Skjerve (2011). Cattle brucellosis in traditional livestock husbandry practice in Southern and Eastern Ethiopia, and its zoonotic implication.

Ndenecho EN (2005). Biological Resource Exploitation in Cameroon: From crises to sustainable management. Unique Printers Bamenda Cameroon: $181 \mathrm{pp}$.

Plummet M, Diaz R and Verger JM (1998). Zoonosis: biology, clinical Practice and public health control: Oxford Univ. Press, New York, USA, pp: 23-35.

Radostits OM, Gay CC, Blood DC and Hinchcliff KW (2000). Veterinary Medicine, 9th Ed., ELBS Bailliere Tindall, London, UK, pp: 870-871.

Refai M (2002). Incidence and control of brucellosis in the Near East region

Schelling E, Diguimbaye C, Daoud S, Nicolet J, Boerlin P, Tanner M and Zinsstag J (2003). Brucellosis and Q-fever seroprevalences of nomadic pastoralists and their livestock in Chad. Preventive Veterinary Medicine 61: $279-293$. 
Shey-Njila O, Awah-Ndukum J, Bayemi PH, Nyah E, Zoli PA, Geerts S (2005). Brucellosis in Cameroon: current status and challenges for the future. The role of Biotechnology in animal agriculture to address poverty in Africa: opportunities and Challenges. Arusha, Tanzania, 23-26 September.

Shey-Njila O (2004). A sero-epidemiological study of bovine brucellosis in the region of Dschang (West, Cameroon).MSc. Thesis ITM Antwerp, Belgium.
SVANOVA (2005). Brucella-Ab, C-ELISA SVANOVIRä. ELISA test for the detection of Brucella antibodies in serum samples discriminating between infected and vaccinated cattle. Manual.

World Health Organization (WHO) (2003). Brucellosis. Geneva, Switzerland.

Cite this Article: Kong AT, Nsongka MV, Itoe SM, Hako AT, Leinyuy I (2016). Seroprevalence of Brucella abortus in the Bamenda Municipal Abattoir of the Western Highlands, of Cameroon. Greener Journal of Agricultural Sciences, 6(8): 245-251, http://doi.org/10.15580/GJAS.2016.8.082216135. 